\title{
The Respirable Organic Matter of Sea Water.
}

\author{
By \\ W. R. G. Atkins, O.B.E., Sc.D., F.I.C., \\ Head of the Department of General Physiology at the Plymouth Laboratory.
}

With 1 Figure in the Text.

THE photosynthetic activity of algæ results in the conversion of carbon dioxide into carbohydrates. These are available for respiration, and within a limited time all, or almost all, the photosynthetic products of one year are broken down again into carbon dioxide and water through the action of plants, animals and bacteria.

The removal of carbonic acid tends to lower the hydrogen ion concentration of the sea water, namely to increase its $\mathrm{pH}$ value. Conversely production of the acid lowers the $\mathrm{pH}$ value. By exposing a plant of Ulva to sunlight in a jar of sea water a reaction of $\mathrm{pH} 9.7$ may be reached, whereas algæ decomposing in a jar in the dark may through bacterial action yield so much carbonic acid as to render the water as acid as $\mathrm{pH} 6 \cdot 4$.

It has long been known that when making accurate determinations of the hydrogen ion concentration of sea water, it is necessary to examine it almost immediately; if this is not done the $\mathrm{pH}$ values obtained are too low. It might be thought that this was due to absorption of carbon dioxide from the air. Sea water does absorb this gas if above about $\mathrm{pH} 8 \cdot 1$, for it is in equilibrium with the concentration in the atmosphere at close to $\mathrm{pH} 8.1$; consequently sea water in spring or autumn at $\mathrm{pH} 8.2$ takes it up. This would not, however, account for the fact that on keeping the water may fall to below $\mathrm{pH} 8$. Furthermore, samples are stored either in bottles almost completely filled and tightly stoppered, or in test tubes closed by rubber caps, which greatly reduces the amount of carbon dioxide that ean gain access.

The source of the additional carbon dioxide which reveals itself in the lowering of the $\mathrm{pH}$ value during storage is accordingly to be sought in the respiration of the plankton algæ and animal organisms, and ultimately, after their death and disintegration, in bacterial action. Bacteria also act upon the waste products of the animal organisms, so it appears 
rational to conclude that any sample of sea water which decreases to a marked extent in $\mathrm{pH}$ value when stored is rich in respirable organic matter. If stored till the $\mathrm{pH}$ value no longer falls the decrease from the original value may be taken as a measure of this in the volume of water examined. It is, of course, possible that resistent spores, etc., may still remain, so the amount indicated is probably less than that given by a method based upon complete oxidation by a powerful oxidising agent such as alkaline permanganate. The method, however, gives results which are comparable inter se and is of great delicacy. Moreover, it is a very rapid one as far as actual time consumed in working is concerned, for it is only necessary to store the test tubes already used for the colorimetric determination of the $\mathrm{pH}$ values. Since, however, even the very stable indicator cresol red fades slowly under these conditions, though not when toluene is added as an antiseptic, it is more accurate to store the sample in its bottle as obtained, and to examine it afresh in the usual way as described in detail in an accompanying paper on "The hydrogen ion concentration of sea water in its biological relations." Obviously the chance presence of a single relatively large organism may give a result which is erroneous for the water as a whole, but as a rule the contents of a sample bottle, about 170 c.c., seem to be truly representative.

On standing a scum develops on the surface of the tubes which show a decrease in $\mathrm{pH}$ value, but it is absent in those which remain constant.

To render the method quantitative it is necessary to ascertain the change in $\mathrm{pH}$ value, over the particular range studied, which the addition of a given amount of carbonic acid produces. For convenience dilute sulphuric acid was used, from which the equivalent quantities of carbonic acid were calculated.

It was found that the addition of 1.00 c.c. of $\mathrm{N} / 100$ acid to 100 c.c. of sea water at $\mathrm{pH} 8 \cdot 06$ changed the latter to $\mathrm{pH} 7 \cdot 97$. It was not possible to study the change in the less acid region as standards of the same degree of accuracy had not been prepared, but it is hoped to prepare them shortly. It may be taken, therefore, that over this range, and without much error slightly outside it, the addition of $0 \cdot 1$ c.c. of $\mathrm{N} / 100$ acid per 100 c.c. of sea water produces a change of $\mathrm{pH} 0 \cdot 01$. To change water from about $\mathrm{pH} 8 \cdot 2$ to the limit for titration with phenolphthalein, viz. about $\mathrm{pH} 7 \cdot 6$, requires only about $2 \cdot 5-3 \cdot 0$ c.c. of acid, since the higher decimal places of a logarithmic scale are close together, as on a slide rule. Over this more extended range the value is $1 \cdot 0$ c.c. to $\mathrm{pH} 0 \cdot 2$ roughly, viz. about $0 \cdot 1$ c.c. for a change of $\mathrm{pH} 0 \cdot 02$.

Now, since the molecular weight of carbonic acid is 62 , and the bicarbonate stage is the limit with phenolphthalein as indicator, $\mathrm{M} / 100^{*}$

\footnotetext{
* When titrating to the bicarbonate stage, carbonic acid behaves as monobasic, hence $\mathrm{M} / 100$ is the same as $\mathrm{N} / 100$.
} 
carbonic acid contains 0.62 grams per litre, or 0.12 grams of carbon. The combined carbon in 1 c.c. is therefore 0.00012 grams, or $12 \times 10^{-6}$ grams per $0 \cdot 1$ c.c. But $0 \cdot 1$ c.c. of $\mathrm{N} / 100$ acid added to 100 c.c. of sea water at $\mathrm{pH} 8.06$ produces a lowering of $\mathrm{pH} 0 \cdot 01$. This is equivalent to adding 0.001 c.c. to each cubic centimetre of sea water, viz. $12 \times 10^{-8}$ grams of carbon when converted into carbonic acid. A change of $\mathrm{pH} 0.01$ in 10 c.c. of sea water under examination corresponds therefore to the addition of $12 \times 10^{-7}$ grams of carbon dioxide, reckoned as carbon, which is derived from respiratory action when taking place in nature. Some of the more recent measurements were made to $\pm \mathrm{pH} 0 \cdot 01$, but the earlier ones were not as accurate, though probably to within $\pm \mathrm{pH} 0.05$ in a series, or to $\pm \mathrm{pH} 0 \cdot 1$ in tubes in which the cresol red had faded through bacterial action.

Water samples were taken for examination at the usual stations, the L series running out from Plymouth Sound to beyond the Eddystone Lighthouse. These and E1 were examined monthly, other stations at longer intervals, as explained in "The hydrogen ion concentration of sea water in its biological relations."

It may be said at once, that in the $\mathrm{L}$ series the change on keeping was usually most rapid and greatest at L1, and decreased as the land was left. On looking at the tubes in a row the alterations were very striking, the tubes showing a blue-pink tint at $\mathrm{pH} 8.2$ and a yellowish colour at $\mathrm{pH} 7 \cdot 4$.

The changes in the different samples of the depth series at E1 were also obvious, especially during the summer months when there did not appear to be much vertical mixing as indicated by these results and the temperatures.

The samples were tinted with indicator and examined in a colorimeter tube, after which each was returned to its own tube and closed with a rubber cap. Owing possibly to a larger amount of bacterial infection and to the acquisition of traces of dust, it was found that samples which had been examined in the colorimeter changed on keeping more rapidly and to a greater extent than those examined in the test tube only. As this was not noticed for some considerable time the results recorded here are not to be considered as absolute values, but they seem to be comparable. The initial values were in all cases close to $\mathrm{pH} 8 \cdot 2$, but as precise determinations to the second place of decimals they had to be rejected on account of an uncertainty in the colorimeter measurements, as explained in another communication.

Samples of August 12th, originally at pH8.2 approximately. Samples taken noon to 2 p.m. 


\begin{tabular}{|c|c|c|c|c|c|c|c|}
\hline \multirow{2}{*}{\multicolumn{2}{|c|}{$\begin{array}{l}\text { Station and depth. } \\
\text { L1, surface }\end{array}$}} & \multirow{2}{*}{$\begin{array}{c}\mathrm{pH} \\
\text { Aug. } 20 . \\
8 \cdot 0\end{array}$} & \multirow{2}{*}{$\begin{array}{c}\text { pH } \\
\text { Aug. } 25 . \\
7 \cdot 7\end{array}$} & \multirow{2}{*}{\multicolumn{2}{|c|}{$\begin{array}{c}\text { Change } \\
\text { from } \mathrm{pH} 8 \cdot 2 \\
\text { 2. on Sept. } 2 \text {. } \\
0 \cdot 6\end{array}$}} & \multicolumn{2}{|c|}{$\begin{array}{r}\text { Temperature and } \\
\text { salinity of Aug. } 12\end{array}$} \\
\hline & & & & & & $16 \cdot 2^{\circ}$ & $34 \cdot 61 *$ \\
\hline L2 , , & & & $7 \cdot 65$ & $7 \cdot 6$ & $0 \cdot 6$ & $15 \cdot 4^{\circ}$ & $35 \cdot 01$ \\
\hline , & & $8 \cdot 0$ & $7 \cdot 75$ & $7 \cdot 7$ & $0 \cdot 5$ & $15 \cdot 3^{\circ}$ & $35 \cdot 09$ \\
\hline , & & $7 \cdot 9$ & $7 \cdot 7$ & $7 \cdot 7$ & 0.5 & $15^{\circ}$ & $35 \cdot 14$ \\
\hline ", & & $8 \cdot 0$ & $7 \cdot 9$ & $7 \cdot 85$ & $0 \cdot 35$ & $15 \cdot 2^{\circ}$ & $35 \cdot 31 *$ \\
\hline ", & & 7.95 & $7 \cdot 8$ & $7 \cdot 5$ & $0 \cdot 7$ & $15 \cdot 5^{\circ}$ & $35 \cdot 10^{*}$ \\
\hline E1 :, & & $8 \cdot 2$ & $7 \cdot 75$ & $7 \cdot 65$ & 0.55 & $16 \cdot 13^{\circ}$ & - \\
\hline E1, $5 \mathrm{r}$ & etres & $8 \cdot 2$ & $7 \cdot 95$ & $7 \cdot 9$ & $0 \cdot 3$ & $16 \cdot 17^{\circ}$ & $35 \cdot 10$ \\
\hline E1, 10 & , & $8 \cdot 3$ & $8 \cdot 2$ & $8 \cdot 15$ & 0.05 & $16 \cdot 13^{\circ}$ & $35 \cdot 11 *$ \\
\hline $\mathrm{E} 1,15$ & , & $8 \cdot 25$ & $7 \cdot 9$ & $7 \cdot 8$ & $0 \cdot 4$ & $16 \cdot 12^{\circ}$ & $35 \cdot 10$ \\
\hline $\mathrm{E} 1,20$ & , & $7 \cdot 9$ & $7 \cdot 65$ & $7 \cdot 65$ & 0.55 & $15 \cdot 46^{\circ}$ & $35 \cdot 14$ \\
\hline $\mathrm{E} 1,25$ & , & $8 \cdot 2$ & 8.05 & $7 \cdot 95$ & $0 \cdot 25$ & $13 \cdot 34^{\circ}$ & $35 \cdot 16$ \\
\hline $\mathrm{E} 1,30$ & , & $8 \cdot 25$ & $8 \cdot 1$ & $8 \cdot 0$ & $0 \cdot 2$ & $13 \cdot 32^{\circ}$ & $35 \cdot 19$ \\
\hline $\mathrm{E} 1,40$ & , & $8 \cdot 25$ & $8 \cdot 15$ & $8 \cdot 1$ & $0 \cdot 1$ & $13 \cdot 30^{\circ}$. & $35 \cdot 19$ \\
\hline E1, 50 & , & $8 \cdot 25$ & $8 \cdot 15$ & $8 \cdot 1$ & $0 \cdot 1$ & $13 \cdot 28^{\circ}$ & $35 \cdot 19$ \\
\hline E1, 60 & , & $8 \cdot 2$ & $8 \cdot 15$ & $7 \cdot 95$ & $0 \cdot 25$ & $13 \cdot 28^{\circ}$ & $35 \cdot 17$ \\
\hline $\mathrm{E} 1,70$ & , & $8 \cdot 2$ & $7 \cdot 85$ & $7 \cdot 8$ & 0.4 & $13 \cdot 28^{\circ}$ & $35 \cdot 13$ \\
\hline
\end{tabular}

It was considered that by September 2 nd the tubes would change no further, which is only approximately true in all probability. A number of similar determinations were made, but owing to the uncertainty introduced by pouring into the colorimeter these have been held over pending further work.

The results of August 12th are shown graphically in the accompanying figure, as are also those of November 9th, for Station E1 in both cases. The November results appear to be the more reliable, as the samples were measured directly into the test tubes and never withdrawn. Moreover, since the initial values were accurately known, and the McClendon series of standard tubes was used, the results are more accurate. The tubes which changed most, however, were compared with the old standards and are not quite as accurate. The fading of the indicator introduces a small error too. For this reason further work will be done on samples stored without indicator.

Viewing the figures here recorded, and those held back, it is seen that in a general way the surface values tend to be higher than those at five and ten metres. There is often, but not always, a notable increase in the amount of change shown between about 20-25 metres. After this low values are obtained down to about 60 metres, where a rise is found, which increases towards the lowest reading, 70 metres; the bottom was actually at 74 metres, but the difference has to be allowed on account of the motion of the ship for fear of damaging the water bottle.

\footnotetext{
* Signifies duplicate titrations.
} 
$\mathrm{pH}$ values of sea water from E1, taken November 9th, 11-1 p.m. and examined at intervals.

$\begin{array}{cccccccc}\begin{array}{c}\text { Depth } \\ \text { in metres. }\end{array} & \begin{array}{c}\text { Nov. } 9 \\ \text { pH. }\end{array} & \begin{array}{c}\text { Nov. 15 } \\ \text { pH. }\end{array} & \begin{array}{c}\text { Feb. 8. } \\ \text { pH. }\end{array} & \begin{array}{c}\text { March 3. } \\ \text { pH. }\end{array} & \begin{array}{c}\text { Maximum } \\ \text { alteration } \\ \text { in } \mathrm{pH} .\end{array} & \begin{array}{c}\text { Temperature and } \\ \text { salinity of water } \\ \text { when drawn. }\end{array} \\ 0_{1} & 8 \cdot 22 & 8 \cdot 03 & 7 \cdot 97 & 7 \cdot 97 & 0 \cdot 25 & 14 \cdot 31^{\circ} & 35 \cdot 35^{\circ} \% \\ 0_{2} & 8 \cdot 23 & 8 \cdot 03 & 8 \cdot 13 & 8 \cdot 09 & 0 \cdot 20 & 14 \cdot 96^{\circ} & 35 \cdot 37^{*} \\ 5 & 8 \cdot 23 & 8 \cdot 09 & 7 \cdot 9 & 7 \cdot 9 & 0 \cdot 33 & 15 \cdot 00^{\circ} & 35 \cdot 33 \\ 10 & 8 \cdot 23 & 8 \cdot 06 & 8 \cdot 14 & 8 \cdot 12 & 0 \cdot 17 & 14 \cdot 96^{\circ} & 35 \cdot 33 \\ 15 & 8 \cdot 23 & 8 \cdot 06 & 8 \cdot 08 & 8 \cdot 08 & 0 \cdot 17 & 15 \cdot 00^{\circ} & 35 \cdot 41 \\ 20 & 8 \cdot 23 & 8 \cdot 16 & 7 \cdot 7 & 7 \cdot 7 & 0 \cdot 53 & 14 \cdot 99^{\circ} & 35 \cdot 32 \\ 25 & 8 \cdot 22 & 8 \cdot 14 & 7 \cdot 7 & 7 \cdot 7 & 0 \cdot 52 & 14 \cdot 96^{\circ} & 35 \cdot 29 * \\ 30 & 8 \cdot 21 & 8 \cdot 08 & 8 \cdot 13 & 8 \cdot 08 & 0 \cdot 13 & 14 \cdot 98^{\circ} & 35 \cdot 33 \\ 40 & 8 \cdot 21 & 8 \cdot 09 & 8 \cdot 12 & 8 \cdot 06 & 0 \cdot 15 & 14 \cdot 95^{\circ} & 35 \cdot 32 \\ 50 & 8 \cdot 21 & 8 \cdot 09 & 8 \cdot 12 & 8 \cdot 04 & 0 \cdot 17 & 14 \cdot 96^{\circ} & 35 \cdot 35 \\ 60 & 8 \cdot 21 & 8 \cdot 15 & 8 \cdot 01 & 8 \cdot 00 & 0 \cdot 21 & 14 \cdot 96^{\circ} & 35 \cdot 38 \\ 70 & 8 \cdot 20 & 8 \cdot 08 & 8 \cdot 01 & 8 \cdot 01 & 0 \cdot 19 & 14 \cdot 98^{\circ} & 35 \cdot 28\end{array}$

On examining the foregoing tables it becomes clear that salinity changes have no connection with the alterations in $\mathrm{pH}$ value on keeping. The same is true for temperature changes in the column of water.

When the changes in $\mathrm{pH}$ value are scrutinised it is seen that they amount to $\mathrm{pH} 0.05$ as a minimum and $\mathrm{pH} 0.7$ as a maximum, or in the depth series at $\mathrm{E} 1, \mathrm{pH} 0.55$ as a maximum. The range corresponds approximately with 0.5 c.c. to 2.5 c.c. of $\mathrm{N} / 100$ acid per 100 c.c. of sea water, or 5 to 25 e.c. per litre. These quantities are equivalent to 0.0006 to 0.003 grams of carbon per litre, or if calculated to the form of carbohydrate, which contains 40 per cent of carbon, to 0.0015 to 0.0075 grams per litre. The amount due to photosynthesis during the second half of the year, as shown in the accompanying paper, is as a minimum 3 milligrams per litre.

This corresponds to an alteration of 1.00 c.c. in the amount of acid required to bring 100 c.c. of sea water to the bicarbonate stage, or very approximately to $\mathrm{pH} 0 \cdot 1$ at around $\mathrm{pH} 8$ and to $\mathrm{pH} 0 \cdot 2$ at about $\mathrm{pH} 7 \cdot 7$. Were there an exact proportionality between the change in $\mathrm{pH}$ or $\mathrm{C}_{\mathrm{H}}$ values and the volume of acid added it would be permissible to compare the areas of the curves shown in the figures by the whole and dotted lines. Since, however, the change is more rapid at the values below $\mathrm{pH} 8$, the right-hand areas of the whole line curves do not exactly correspond with equal increments of added acid. Pending the preparation of a curve showing, more accurately than has been done so far, the relation between the two it is permissible to say that almost all the samples show a greater change on storing than could be accounted for by the decomposition of

\footnotetext{
* Signifies duplicate titrations.
} 
three milligrams per litre of a hexose sugar. In fact, the amount seems to be between once and a half and twice as great, probably nearer the former value. For complete oxidation three milligrams per litre of a hexose would require $3 \cdot 2$ milligrams of oxygen.

Organic matter in water is usually estimated by means of permanganate solutions; the solutions used are sometimes acid, sometimes alkaline, and the temperatures and times of experiment are also diverse. The results are, therefore, only strictly comparable if carried out under identical conditions. Furthermore, carbon in nitrogenous compounds

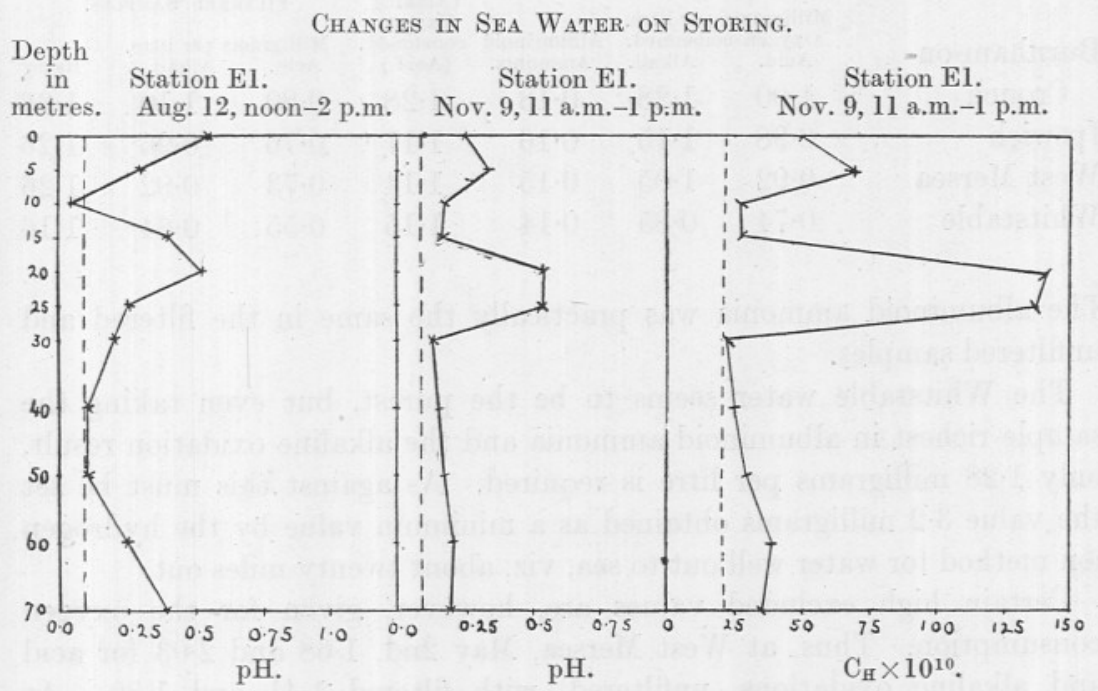

Decrease in alkalinity in terms of $\mathrm{pH}$. Ditto in terms of $\mathrm{C}_{\mathrm{H}}$.

The dotted line shows the change produced by adding $\mathrm{l} \cdot 00 \mathrm{c}$.e. of $\mathrm{N} / 100 \mathrm{H}_{2} \mathrm{SO}_{4}$ to sea water, at $\mathrm{pH} 8.06,100$ c.c.
Area of curve (Aug.) 660 units.
Area of eurve (Nov.) 580 units.
Area of curve (Nov.)
1,240 units.

Area of dotted curve, 280 units . . . . . . . .

is more resistant to oxidation than that in carbonaceous organic matter. The official method of the American Public Health Association specifies boiling for thirty minutes with an acid solution. The methods used in the Government Chemist's Laboratory, London, are (a) treatment in an acid solution for four hours at $80^{\circ} \mathrm{F}$. and (b) boiling for ten minutes in an alkaline solution. It is customary to use 100 c.c. of the sample, or a convenient amount diluted to that volume, and permanganate of which 1 c.c. is equivalent to $0 \cdot 1$ milligram of available oxygen. The writer is indebted to Dr. J. H. Orton for drawing his attention to certain unpublished results of analyses carried out by the Government Chemist on 
samples taken from estuarine oyster beds by Dr. W. Wallace, by whose courtesy the following estimations are quoted, since no direct determinations of the oxygen consumed by organic matter in sea water at Station $\mathrm{E} 1$ have as yet been made.

The results are shown in the following table, based on averages for seventy-six samples, and excluding twelve with abnormally high results. The samples were of surface water, taken at various times throughout the year.

\begin{tabular}{|c|c|c|c|c|c|c|c|}
\hline \multirow{3}{*}{$\begin{array}{l}\text { Burnham-on- } \\
\text { Crouch }\end{array}$} & \multicolumn{3}{|c|}{ UNFILTERED SAMPLES. } & \multirow{2}{*}{$\begin{array}{c}\text { Ratio, } \\
\text { Oxygen } \\
\text { consumed. } \\
\text { (Alkali.) } \\
\text { Oxygen } \\
\text { consumed. } \\
\text { (Acid.) }\end{array}$} & \multicolumn{3}{|c|}{ Filtered SAMples. } \\
\hline & $\begin{array}{l}\text { Oxygen } \\
\text { Acid. }\end{array}$ & $\begin{array}{l}\text { onsumed. } \\
\text { Alkali. }\end{array}$ & $\begin{array}{l}\text { Albuminoid } \\
\text { Ammonia. }\end{array}$ & & $\begin{array}{l}\text { Milligrams } \\
\text { Acid. }\end{array}$ & $\begin{array}{l}\text { per litre. } \\
\text { Alkali. }\end{array}$ & Ratio \\
\hline & $1 \cdot 00$ & $1 \cdot 28$ & $0 \cdot 18$ & $1 \cdot 28$ & $0 \cdot 80$ & $1 \cdot 10$ & $1 \cdot 38$ \\
\hline Ipswich & 0.98 & $1 \cdot 15$ & $0 \cdot 16$ & $1 \cdot 17$ & $0 \cdot 76$ & 0.96 & $1 \cdot 26$ \\
\hline West Mersea & 0.92 & 1.05 & $0 \cdot 15$ & $1 \cdot 14$ & $0 \cdot 73$ & 0.92 & $1 \cdot 26$ \\
\hline Whitstable & $0 \cdot 74$ & $0 \cdot 85$ & $0 \cdot 14$ & $1 \cdot 15$ & 0.55 & $0 \cdot 64$ & $1 \cdot 16$ \\
\hline
\end{tabular}

The albuminoid ammonia was practically the same in the filtered and unfiltered samples.

The Whitstable water seems to be the purest, but even taking the sample richest in albuminoid ammonia and the alkaline oxidation result, only 1.28 milligrams per litre is required. As against this must be set the value $3 \cdot 2$ milligrams obtained as a minimum value by the hydrogen ion method for water well out to sea, viz. about twenty miles out.

Certain high excluded values are, however, given for the oxygen consumption. Thus, at West Mersea, May 2nd, 1.68 and 2.03 for acid and alkaline oxidations, unfiltered, with filtered 1.41 and 1.80 . At Whitstable, March 12th, 2.98 and $3 \cdot 13$, with filtered 1.36 and 1.50 . At Burnham, February 20th, $4 \cdot 44$ and $5 \cdot 61$, with filtered $3 \cdot 94$ and $5 \cdot 14$. It might be thought curious that the results for unfiltered water should be so little higher than those for filtered, but many plankton organisms, such as minute diatoms and flagellates, pass through ordinary filter paper. It may be noted that even at $\mathrm{E} 1$ with water close to $\mathrm{pH} 8 \cdot 2$ a fall to $\mathrm{pH} 7 \cdot 7$ was observed, corresponding to about 2.5 c.c. of acid, to $7.5 \mathrm{mgrms}$. of a hexose, and consequently to 8.0 mgrms. of oxygen.

There is certainly a considerable discrepancy between the results for oxygen consumed as determined by the permanganate methods, and by changes in $\mathrm{pH}$ values. The latter have been calculated on the assumption that a hexose is oxidised, and accordingly are minimum values, for fats and other carbonaceous substances, except organic acids, are less highly oxygenated than hexoses.

In the absence of direct comparisons on the same sample of water, it would be unwise to go in detail into the causes of the discrepancy, 
but it appears that the permanganate results may be too low owing to the fact that they correctly indicate the relative magnitudes of the quantities of oxidisable organic matter in the water at the time the estimation is made. These amounts are certainly not those in the water when the bottles were filled, if, as is usually the case with samples sent away for analysis, several days necessarily elapse, and possibly several weeks, between collection and estimation. This is shown by the fall in the $\mathrm{pH}$ value which, in the case of the $\mathrm{L}$ series for August 12th, as recorded previously, decreased by as much as $\mathrm{pH} 0 \cdot 3$ in eight days or $\mathrm{pH} 0 \cdot 5$ in thirteen days, after which it changed but little. Analysis after this period would obviously show only the oxygen consumption of the matter which could not be completely oxidised by the organisms present and under natural conditions. It is, in fact, comparable to estimating a solution of glucose sown with yeast after several days' fermentation and taking this as a measure of the original concentration. More accurate results would most likely be obtained by the permanganate method applied to fresh samples, or by adding the amounts indicated by the fall in $\mathrm{pH}$ value to those for the residual matter as found by permanganate after storing.

In any case it seems that the very considerable differences shown by water from various stations and at different depths at the same place are to be taken as a measure of the amount of the minute plankton present. For this reason the storing of a bottle of water seems preferable to the storing of 10 c.c., as the bottle will contain copepods, which are unlikely to be drawn up into the pipette, yet three or four per bottle increase the amount of organic matter considerably. It is hoped that the matter may be investigated more fully.

Since the foregoing paragraphs were written analyses of organic matter in sea water made by Raben (Wissensch. Meeresuntersuch., XI, Kiel, $1910,111-117$ ) have come to the writer's notice. The sea water was filtered through a Berckefeld filter and was analysed at once, also two days later, the latter appear to give lower values within the limits of error. The results are given in organically combined carbon, which may be converted into hexose by the factor $2 \cdot 5$. For the Kiel Ford values of 13.9-11.4 milligrams per litre of carbon were obtained, for a Baltic Sea station 3.0 mgrms. This corresponds to 7.5 mgrms. of a hexose, agreeing well with some of the E1 figures, although for completely filtered water. 


\section{SUMMARY.}

1. On storing, sea water suffers a decrease in $\mathrm{pH}$ value. The amount of change varies from that produced by adding $1 \cdot 0$ c.c. of $\mathrm{N} / 100$ acid to 100 c.c. of sea water, up to that due to adding about $2 \cdot 5-3 \cdot 0$ c.c. The decrease is due to the production of carbonic acid by organisms.

2. The change corresponding to $1 \cdot 0$ c.c. of acid, as above, is equivalent to that produced by the complete oxidation of 3 milligrams per litre of a hexose sugar, which requires 3.2 mgrms. per litre of oxygen. This is the minimum value, from $8 \cdot 0-9 \cdot 6$ mgrms. corresponds to the higher values of acid. Figures for oxygen consumption by estuarine waters, which are available for an approximate comparison, show that $1.5 \mathrm{mgrms}$. of oxygen is not often exceeded in estimations by means of alkaline permanganate. The highest of this series is $5 \cdot 6$ mgrms. It is suggested that the different results given by the two methods are due to the fact that respiratory changes taking place in the water during storage set free much of the organically combined carbon before the oxidation by permanganate has been started. Determinations on freshly drawn filtered sea water give, according to Raben, 7.5 mgrms. of hexose or $8.0 \mathrm{mgrms}$. of oxygen consumed.

3. It is probable that the change in $\mathrm{pH}$ value on storing indicates the amount of plankton present, at any rate when sewerage contamination is negligible. It appears that water near the surface, at 20-25 metres and sometimes at the bottom, 70 metres, is particularly subject to change during storage. Four cases out of seven showed marked decreases in $\mathrm{pH}$ value at $20-25$ metres, and two others exhibited the change to a less marked degree.

4. The total amount of carbon, reckoned as hexose, which is set free during storage by respiration in sea water at E1 is about twice that photosynthesised between July and December, taking for this the minimum value 3 mgrms. per litre, namely a total of 6 mgrms. per litre. Considering the column of water from bottom to surface, this is equivalent to about 500,000 kilograms per square kilometre in the English Channel off Plymouth. 